\section{Index for 1996}

Page number references to Volume 19 are listed. Abbreviations: A, article; BR, book review; $C R$, conference report; $E$, editorial; $\mathrm{L}$, letter to the Editor; NR, news report.

Africa.

See IGCP Project 363: Palaeoproterozoic of sub-equatorial Africa. (CR);

Muhongo, Sospeter (A); IGCP Project

348: Mozambique and related belts (CR).

Afro-Asian Association of Petroleum Geochemists.

4th international conference (1996) (CR) 86 . AGID.

See Reedman, A J R (A).

Allen, P M.

The Grampian Highlands (4th edition)

(L) 140 .

Annells, Richard.

EuroGeoSurveys (A) 61.

Appleton, J D, Fuge, R and McCall, G J H (eds.). Environmental geochemistry and health (BR by McMichael) 89 .

Applied geological remote sensing. 1996 conference (CR) 30.

Asia.

See Kim Sahng-Yap (A); Biogeography and geological evolution of SE Asia (CR).

Biogeography and geological evolution of SE Asia.

1996 meeting contributing to IGCP Projects 321,306 and 355 (CR) 25.

Biomineralogy. See Mineralogy and life: biomineral interactions (CR).

Branagan, David. See Schneer, Cecil (BR).

Brasier, M D.

$\mathrm{U} / \mathrm{Pb}$ dates for the base of the terminal Proterozoic and Cambrian (L) 91.

Bryron, Dave.

See Sowerbutts, Bill and Byron, Dave (A)

Caldwell, W G E.

See Fyfe, W S and Caldwell, W G E (A) 21.

Cambrian biostratigraphy.

See IGCP Project 366: Ecological

aspects of Cambrian radiation (CR)

Caribbean.

See IGCP Project 364: Correlation of

Caribbean ophiolites and volcanic arcs (CR).

CCOP.

See Kim Sahng-Yap (A)

Chronostratigraphic standards.

See Remane, Jürgen and others (A).

Cobbing, John.

Granites-an overwiew (A) 103.

Coleman, Tim.

See Kirkham, R V and others (eds.) (BR).

Computer-aided learning.

See Sowerbutts, Bill and Byron, Dave (A).

Conservation of geological sites.

See GEOSITES-a new conservation initiative (NR).

Derbyshire, Edward

See Robinson, D A and Williams, R B G (eds.) (BR).
Emplacement of granite.

See Hutton, Donald H W (A).

Environmental and legislative uses of regional geochemical baseline data for sustainable development. 1996 workshop (CR) 31.

Environmental geochemistry. See Appleton, J D, Fuge, R and McCall G J H (eds.) (BR)

EuroGeoSurveys. See Annells, Richard (A).

European Union, geoscience in. See Annells, Richard (A)

Fox, R A, Knight, W V and Williams, J H. Professional geology and regulation (A) 74 .

Fractals and dynamic systems in geoscience. 1995 symposium (CR) 27.

Fyfe W S.

Reflections from the retiring President of IUGS (E) 2; see also Holland, H D and Peterson, U (BR)

Fyfe, W S and Caldwell, W G E. Earth sciences and global development an IUGS perspective (A) 21;

Geochemistry and health See Appleton, J D, Fuge, R and McCall, G J H (eds.) (BR).

Geological Society of Africa. See GSA '95 (CR); Muhongo, Sospeter (A).

Geoscience and development-the role of AGID.

See Reedman, A J R (A)

GEOSITES-a new conservation initiative (NR) 87.

Global Geosites Working Group. See GEOSITES-a new conservation initiative (NR)

Gondwanaland. See Unrug, Raphael (A); Sorkhabi, Rasoul B (A).

Gradstein, F $M$ and $O g g$, J. A phanerozoic time scale (A) 3 .

Grampian Highlands.

See Stephenson, D and Gould, D (BR); Allen, P M (L).

Granite.

See Cobbing, John (A); Harris, Nigel (A): Hutton, Donald H W (A); Pearce, Julian (A); Sillitoe, Richard H (A).

GSA' 95 1995 conference on geology for development within a sustainable environment. (CR) 85 .

Gulf PetroLink. GeoArabia a new journal (BR by Whittaker) 90

Harris, Nigel.

Radiogenic isotopes and the interpretation of granitic rocks (A) 107.

Himalayan geology. See Upreti, B N and Dhital, M R (BR); Networking amongst Himalayan researchers (NR).

Holland, H D and Peterson, U. Living dangerously (the Earth, its resources and the environment (BR by Fyfe) 43.
Hutton, Donald H W

The 'space problem' in the emplacement of granite (A) 114.

ICS.

See Remane, Jürgen and others (A).

IGCP Project 288: Gondwanaland sutures and fold belts.

See Unrug, Raphael (A) 11.

IGCP Project 306: Stratigraphic correlation in SE Asia.

See Biogeography and geological evolution of SE Asia (CR).

IGCP Project 321: Gondwana dispersion and accretion.

See Biogeography and geological evolution of SE Asia (CR).

IGCP Project 348: Mozambique and related belts.

1996 field meeting in Ethiopia and Eritrea (CR) 28.

IGCP Project 349: Desert margins and palaeomonsoons since $135 \mathrm{ky} \mathrm{BP}$. 1995 conference on Quaternary deserts and climatic change (CR) 33 .

IGCP Project 354: Economic super-accumulations of metals in the lithosphere. Workshop (1995) on the relationships between metal concentrations and deep structures of the lithosphere (CR) 24 .

IGCP Project 355: Neogene evolution of Pacific Ocean gateways.

See Biogeography and geological evolution of SE Asia (CR).

IGCP Project 363: Palaeoproterozoic of subequatorial Africa.

1996 conference and field workshop (CR) 137.

IGCP Project 364: Correlation of Caribbean ophiolites and volcanic arcs. 1996 symposium (CR) 27.

IGCP Project 366: Ecological aspects of Cambrian radiation. 1996 field meeting (CR) 136.

IGCP Project 380: Microbialites - processes and products.

1996 meeting (CR) 134.

Index for 1995 .

51.

Isotopes, in granitic rocks. See Harris, Nigel (A).

IUGS.

Financial statement for 1995 and budget for 1996 (NR) 38. See also Fyfe, W S (E); Fyfe, W S and Caldwell, W G E (A);

James Hutton plaque fund. (NR) 40

Kim Sahng-Yap. CCOP-an intergovernmental organisation in East and Southeast Asia (A) 55.

Kirby, Gary. See Wagoner, J C Van (BR).

Kirkham, R V and others (eds.). Mineral deposit modelling (Papers presented during 8th IAGOD meeting, 1990) (BR by Colman) 139.

Lithosphere, metals in.

See IGCP Project 354: Economic superaccumulations of metals in the lithosphere (CR). 
Magoon, L B and Dow, W G (eds.). The petroleum system-from source to trap (BR by Whittaker) 43 .

McMichael, A J. See Appleton, J D, Fuge, R and McCall, G J H (eds.) (BR).

Metal deposits and granite. See Sillitoe, Richard H (A).

Mineralogy and life: biomineral interactions. 1996 seminar (CR) 26.

Mozambique belt. See IGCP Project 348: Mozambique and related belts (CR).

Muhongo, Sospeter. The Geological Society of Africa-role and objectives for the 21 st century (A) 66 .

Networking amongst Himalayan researchers. (NR) 36.

Ogg, J. See Gradstein, F M and Ogg, J (A)

Ophiolites. See IGCP Project 364: Correlation of Caribbean ophiolites and volcanic arcs (CR).

Pearce, Julian.

Sources and settings of granitic rocks (A) 120 .

Peat.

10th international congress (1996) (CR) 85 .

Peter Cook awarded CBE. (NR) 40.

Petroleum geology. See Gulf PetroLink (BR); Afro-Asian Association of Petroleum Geochemists (CR); Magoon, L B and Dow, W G (eds.) (BR).

Phanerozoic time scale. See Gradstein, F M and Ogg, J (A)

Professional geology and regulation. See Fox, R A, Knight, W V and Williams, J H (A)
Quaternary.

See IGCP Project 349: Desert margins and palaeomonsoons since $135 \mathrm{ky} \mathrm{BP}$ (CR).

Reedman, A J R.

Geoscience and development-the role of AGID (A) 71.

Regional geochemical data.

See Environmental and legislative uses of regional geochemical baseline data for sustainable development (CR).

Regional organisations in geoscience. See Walshaw, R D (E); Annells, Richard (A); Kim Sahng-Yup (A); Muhongo, Sospeter (A); Reedman, A J (A).

Remane, Jürgen and others.

Revised guidelines for the establishment of global chronostratigraphic standards by the International Commission on Stratigraphy (ICS) (A) 77.

Remote sensing. See Applied geological remote sensing (CR).

Robinson, D A and Williams, R B G (eds.). Rock weathering and landform evolution (BR by Derbyshire) 42 .

Schneer, Cecil.

History of geology - an international happening - the geologists at Prague: August 1968 (BR by Branagan) 139.

Shackleton, Robert.

See Stephenson, D and Gould, D (BR); Allen, P M (L).

Sillitoe, Richard $\mathrm{H}$. Granites and metal deposits (A) 126.

Skinner, B J.

See Sutherland, F L (BR).

Sorkhabi, Rasoul B.

What's in a name- 'Gondwana' or 'Gondwanaland'? (A) 83.

Sources and tectonic settings of granite. See Pearce, Julian (A).

Sowerbutts, Bill and Byron, Dave. Courseware for earth science teaching and learning (A) 7 .
Spencer, David A.

See Upreti, B N and Dhital, M R (BR).

Stephenson, D and Gould, D.

The Grampian Highlands (4th edition) (BR by Shackleton) 89. See also Allen, P $M(L)$.

Stratigraphic Guidelines. See Remane, Jürgen and others (A).

Stromatolites. See IGCP Project 380: Microbialites processes and products (CR).

Sutherland, F L. The volcanic Earth (BR by Skinner) 42 .

Teaching earth science. See Sowerbutts, Bill and Byron, Dave (A).

Thomas, Bob. See Yoshida, M and Santosh, M (eds.) (BR).

$\mathrm{U} / \mathrm{Pb}$ dates for the base of the terminal Proterozoic and Cambrian. See Brasier, M D (L).

UKESCC.

See Sowerbutts, Bill and Byron, Dave (A). Unrug, Raphael.

The assembly of Gondwanaland (A) 11 .

Upreti, B N and Dhital, M R.

Proceedings of the 9th

Himalaya-Karakoram-Tibet workshop (BR by Spencer) 45 .

Volcanic arcs. See IGCP Project 364: Correlation of Caribbean ophiolites and volcanic arcs (CR).

Wagoner, J C Van. Sequence stratigraphy of foreland basin deposits (BR by Kirby) 140.

Walshaw, R D. Regional organisations in geoscience $(\mathrm{E})$ 54; Episodes is moving to China (E) 102.

Whittaker, A. See Gulf PetroLink (BR); Magoon, L B and Dow, W G (eds.) (BR).

Yoshida, $M$ and Santosh, M (eds.). India and Antarctica during the Precambrian (BR by Thomas) 41 . 